\title{
Sub-decadal- to decadal-scale climate cyclicity during the Holsteinian interglacial (MIS 11) evidenced in annually laminated sediments
}

\author{
A. Koutsodendris ${ }^{1}$, A. Brauer ${ }^{2}$, H. Pälike ${ }^{3}$, U. C. Müller ${ }^{1}$, P. Dulski ${ }^{2}$, A. F. Lotter ${ }^{4}$, and J. Pross ${ }^{1}$ \\ ${ }^{1}$ Paleoenvironmental Dynamics Group, Institute of Geosciences, Goethe University Frankfurt, Altenhöferallee 1, \\ 60438 Frankfurt, Germany \\ ${ }^{2}$ German Research Centre for Geosciences, Section 5.2 Climate Dynamics and Landscape Evolution, Telegrafenberg, \\ 14473 Potsdam, Germany \\ ${ }^{3}$ National Oceanography Centre, Southampton, University of Southampton, Waterfront Campus, European Way, \\ SO14 3ZH Southampton, UK \\ ${ }^{4}$ Institute of Environmental Biology, Palaeoecology, Laboratory of Palaeobotany and Palynology, Utrecht University, \\ Budapestlaan 4, 3584 CD Utrecht, The Netherlands
}

Received: 29 March 2011 - Published in Clim. Past Discuss.: 29 April 2011

Revised: 18 August 2011 - Accepted: 19 August 2011 - Published: 21 September 2011

\begin{abstract}
To unravel the short-term climate variability during Marine Isotope Stage (MIS) 11, which represents a close analogue to the Holocene with regard to orbital boundary conditions, we performed microfacies and time series analyses on a $\sim 3200$-yr-long record of annually laminated Holsteinian lake sediments from Dethlingen, northern Germany. These biogenic varves comprise two sub-layers: a light sub-layer, which is controlled by spring/summer diatom blooms, and a dark sub-layer consisting mainly of amorphous organic matter and fragmented diatom frustules deposited during autumn/winter. Time series analyses were performed on the thickness of the light and dark sub-layers. Signals exceeding the $95 \%$ and $99 \%$ confidence levels occur at periods that are near-identical to those known from modern instrumental data and Holocene palaeoclimatic records. Spectral peaks at periods of 90,25 , and $10.5 \mathrm{yr}$ are likely associated with the 88-, 22- and 11-yr solar cycles, respectively. This variability is mainly expressed in the light sublayer spectra, suggesting solar influence on the palaeoproductivity of the lake. Significant signals at periods between 3 and $5 \mathrm{yr}$ and at $\sim 6 \mathrm{yr}$ are strongest expressed in the dark sub-layer spectra and may reflect an influence of the El Niño-
\end{abstract}

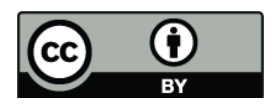

Correspondence to: A. Koutsodendris (koutsodendris@em.uni-frankfurt.de)
Southern Oscillation (ENSO) and the North Atlantic Oscillation (NAO) during autumn/winter. Our results suggest that solar forcing and ENSO/NAO-like variability influenced central European climate during MIS 11 similarly to the present interglacial, thus demonstrating the comparability of the two interglacial periods at sub-decadal to decadal timescales.

\section{Introduction}

An understanding of the mechanisms and effects of natural short-term (i.e. decadal- to sub-decadal-scale) climate variability is essential for providing projections of possible climate change for the near future. Short-term climate changes are linked to shifts in the modes of variability of the climate system (e.g. the southern and northern annular modes; Stenseth et al., 2003); therefore, a better representation of such climate-mode shifts in climate models may improve simulations of abrupt climate changes (Alley et al., 2003). Although the instrumental record is becoming more valuable as it is lengthened, it is still insufficient to cover the full range of climatic behavior. Specifically, instrumental datasets do not reach beyond the past $\sim 300 \mathrm{yr}$ (Jones and Mann, 2004), which precludes deeper insights into the underlying physical processes and the evolution of decadal- to sub-decadal-scale climate variability on longer (e.g. interglacial) timescales. In

Published by Copernicus Publications on behalf of the European Geosciences Union. 
this context, high-resolution palaeoclimate records, particularly from past interglacials that, unlike the Holocene, were unaffected by human interference, can make an important contribution towards elucidating natural short-term climate variability and its future evolution during the present interglacial (e.g. Alley et al., 2003; Brauer et al., 2007; Müller and Pross, 2007; Tzedakis et al., 2009).

Marine Isotope Stage (MIS) 11 is considered one of the best analogues for present and future climate based on long-term similarities with regard to orbital climate forcing, i.e. low eccentricity and dampened influence of precession (e.g. Berger and Loutre, 2002; Loutre and Berger, 2003; Ruddiman, 2005). A number of proxy datasets have provided insights into the long-term comparability between MIS 11 and the present interglacial (e.g. McManus et al., 2003; de Abreu et al., 2005; Helmke et al., 2008; Rohling et al., 2010; Tzedakis, 2010), but owing to a lack of data with sufficiently high temporal resolution, the short-term comparability between the two interglacials has remained ambiguous.

In contrast to most marine records from MIS 11, which typically exhibit relatively low sedimentation rates, varved sequences from lake sediments yield the potential to test whether MIS 11 and MIS 1 exhibit comparable decadal to sub-decadal climate variability. The terrestrial analogue to MIS 11 in Central Europe has long been a matter of heated debate (e.g. Sarnthein et al., 1986; de Beaulieu et al., 2001; Geyh and Müller, 2005; see also Koutsodendris et al., 2010, for a discussion). However, based on evidence from long terrestrial and marine vegetation records from the Massif Central (France; Reille et al., 2000) and off Iberia (Desprat et al., 2005), there is now a substantial body of research that indicates a land-sea correlation of MIS 11c with the Holsteinian interglacial (e.g. de Beaulieu et al., 2001; Kukla, 2003; Nitychoruk et al., 2005, 2006; Müller and Pross, 2007; Preece et al., 2007).

The variations in the composition and thickness of varves reflect sedimentation processes that are controlled by various climatic and environmental factors at different times of the year (e.g. O'Sullivan, 1983; Lotter, 1989; Anderson, 1992; Lotter and Birks, 1997; Brauer et al., 1999a; Brauer, 2004). Deeper insights into these processes have been gained through the time series analysis of varve thickness datasets; such efforts have successfully linked cyclical patterns in lake sediments with short-term natural periodic climate forcing (e.g. Anderson and Koopmans, 1963; Anderson, 1992; Zolitschka, 1992; Vos et al., 1997; Rittenour et al., 2000; Livingstone and Hajdas, 2001). To date, although several well-preserved Holsteinian varved archives are known (e.g. Turner, 1970; Müller, 1974; Krupiński, 1995; Nitychoruk et al., 2005), the potential of using varves to better understand the decadal to sub-decadal-scale climate variability during MIS 11 has been poorly explored (Mangili et al., 2005, 2007; Brauer et al., 2008).

In light of the above, we here analyze a 3200-yr-long Holsteinian varve succession from the Dethlingen palaeo-

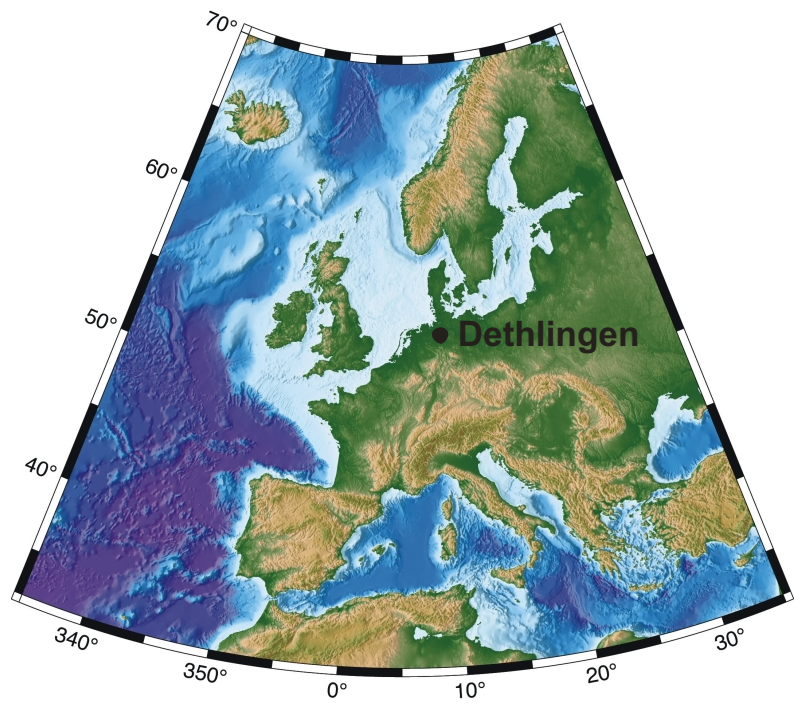

Fig. 1. Map indicating the location of the Dethlingen palaeolake.

lake in northern Germany. In particular, we have performed (i) a detailed microfacies analysis to understand the seasondependent sedimentological processes controlling varve deposition, and (ii) time series analyses on the varve sublayers thickness in order to investigate the short-term climate cyclicity during MIS 11 and to compare it with the instrumental data and palaeoclimatic records of the Holocene.

\section{Material and methods}

The Dethlingen palaeolake is located in the Lüneburger Heide region within the lowlands of northern Germany (Fig. 1). After the disintegration of the Elsterian (MIS 12) ice sheet, several deep lakes formed in the vicinity of Dethlingen that were subject to the deposition of diatomaceous, partially annually laminated sediments during the following Holsteinian interglacial (e.g. Benda and Brandes, 1974; Ehlers et al., 1984). Based on the spatial extent and thickness of the Holsteinian diatomite, the size of the Dethlingen palaeolake is estimated to be $\sim 800 \mathrm{~m}$ in length and 300-500 $\mathrm{m}$ in width (Benda et al., 1984). The deposits cored at Dethlingen $\left(10^{\circ} 08.367^{\prime} \mathrm{E}, 52^{\circ} 57.780^{\prime} \mathrm{N}\right.$, $65 \mathrm{~m}$ a.s.1.) that have yielded the material for this study comprise organic-rich, predominantly regularly and finely laminated lake sediments (Koutsodendris et al., 2010). Here we focus on the interval between 27.93 and 33.68 meters below surface (mbs) that comprises annual laminations spanning the mesocratic forest phase of the Holsteinian interglacial in Central Europe ( 411-408 ka BP), including a prominent centennial-scale climate perturbation, the so-called "Older Holsteinian Oscillation" (OHO; Koutsodendris et al., 2010; Koutsodendris, 2011). 
Varve counting and sub-layer-thickness measurements were carried out at $100 \mathrm{x}$ magnification on thin sections (size: $120 \times 35 \mathrm{~mm}$ ) using a petrographic microscope. Thinsection preparation followed standard techniques comprising freeze-drying, impregnation with Araldite 2020 epoxy resin under vacuum, sawing, and grinding of the sediment (Brauer et al., 1999b; Lotter and Lemcke, 1999). To warrant continuity of observation, successive thin sections with an overlap of $2 \mathrm{~cm}$ were analyzed.

Geochemical measurements were undertaken with a micro-X-ray fluorescence ( $\mu$-XRF) spectrometer EAGLE III XL (GFZ Potsdam) using a step size of $100 \mu \mathrm{m}$ for Al, Ca, $\mathrm{Fe}, \mathrm{K}, \mathrm{Mn}, \mathrm{S}, \mathrm{Si}, \mathrm{Sr}$, and $\mathrm{Ti}$ (50 s count time, $40 \mathrm{kV}$ tube voltage and $400 \mu \mathrm{A}$ tube current). Measurements were carried out on sediment blocks that had been impregnated with Araldite 2020 epoxy resin.

Time series analyses were carried out on the thickness measurements of the light and dark sub-layers. Multi-taper spectral analysis (MTM) was used for spectral estimation (bandwidth parameter $p=5$, and 9 tapers) (e.g. Vautard et al., 1992). The MTM represents an optimal method for producing spectral estimates with high frequency resolution for given degrees of freedom, low bias, and a distribution amenable to the location of confidence levels (Mann and Lees, 1996). In addition, wavelet analysis was applied to identify occurrence intervals and related amplitudes of periodic components of the non-stationary sub-layer thickness time series (Torrence and Compo, 1998).

\section{Results and discussion}

\subsection{Structure of varves and depositional processes}

The finely laminated sediments from Dethlingen comprise biogenic varves consisting of two discrete sub-layers, a light and a dark one. The boundaries between the light and dark sub-layers are marked by conspicuous changes in their composition. In general, the boundaries between the light and dark sub-layers are somewhat less sharp than the boundaries between the dark sub-layers and the light sub-layers of the following varves (Fig. 2a-c). The distinctly differing composition of the individual sub-layers allows unequivocal definition of their boundaries under a petrographic microscope and thus precise measurements of their thicknesses. In the case of less well-preserved sub-layer boundaries (192 varves), the midpoints of the unclear transitional zones between the distinct parts of the sub-layers have been applied for thickness measurements. The uncertainty range for the thickness measurements of well-preserved varves is $\sim 0.01 \mathrm{~mm}$ and up to $0.05 \mathrm{~mm}$ for poorly preserved varves.

The composition and thickness of the light sub-layers are predominantly controlled by the annual cycle of diatom blooms, which is dominated by taxa of the genera Stephanodiscus, Ulnaria, and Aulacoseira. In most cases,

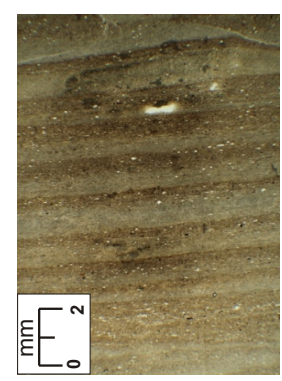

(A)

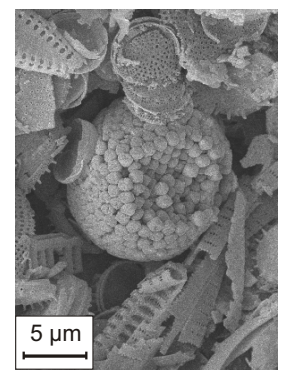

(D)

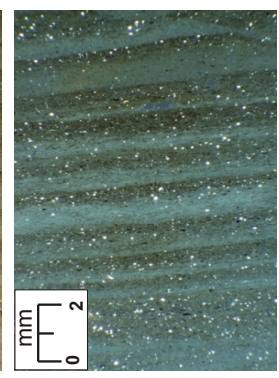

(B)

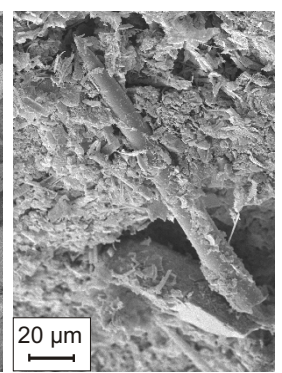

$(\mathrm{E})$

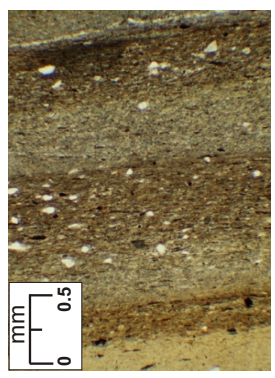

(C)

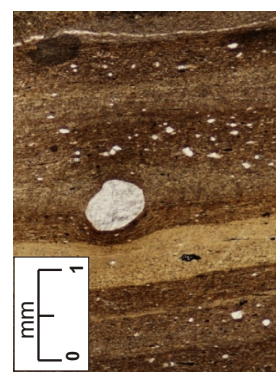

(F)
Fig. 2. Thin-section and scanning electron microscope photographs of varves from the Dethlingen core: light and dark sublayers (A) under parallel-polarized light and (B) under crosspolarized light; (C) close-up photograph of successive dark and light sub-layers; (D) pyrite framboids; (E) sponge spicule; (F) windtransported fine sand grain.

the light sub-layers are dominated by one of these genera, resulting in an almost monospecific diatomaceous layer. However, a successive deposition of two sub-layers of different genera during the growing season can be also observed. The light sub-layers often contain organic matter that increases in abundance towards the boundary with the dark sub-layers. Small-sized $(<10 \mu \mathrm{m})$ pyrite framboids are often present (Fig. 2d) and occasionally few angular-shaped grains, ranging in size from coarse silt to fine sand, are scattered within the light sub-layers (Fig. 2f).

The dark sub-layers are composed predominantly of amorphous organic matter with fragments of diatom frustules. Reworked periphytic diatoms, plant remains, freshwater sponge spicules from the littoral zone, and chrysophycean cysts are common (Figs. 2e, 3a-b). The dark sub-layers often contain low concentrations of clay particles, in contrast to the light sub-layers where fine-grained minerogenic particles are almost absent.

The succession and characteristics of the individual varve sub-layers as described above suggest that the diatomaceous light sub-layers were deposited during spring and summer, whereas the organic-detrital dark sub-layers were formed during autumn and winter (e.g. O'Sullivan, 1983; Lotter, 1989; Brauer, 2004). In particular, the water circulation and high nutrient availability in spring and summer promoted diatom blooms that led to the deposition of diatoms frustules 


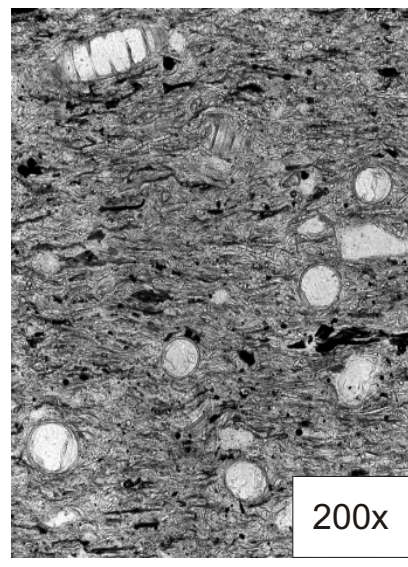

(A)

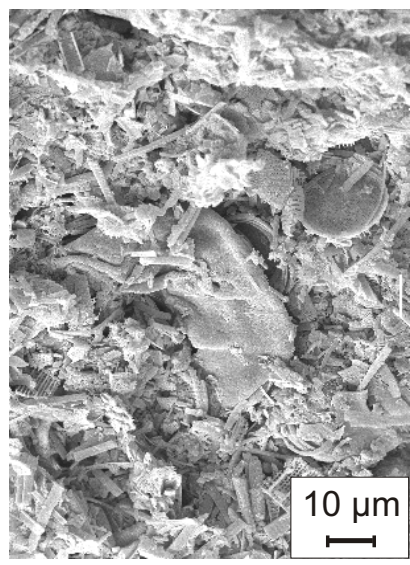

(B)

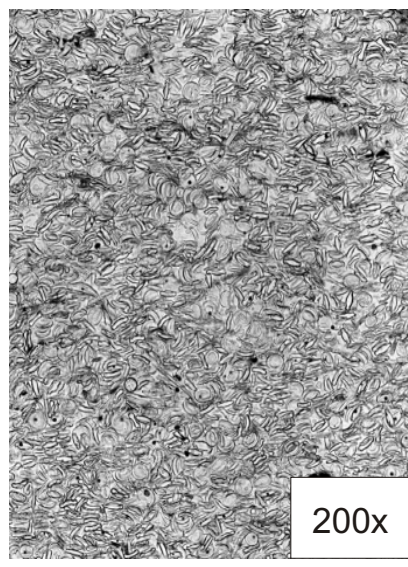

(C)

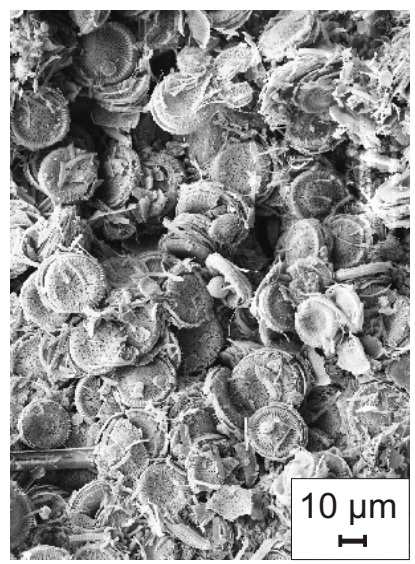

(D)

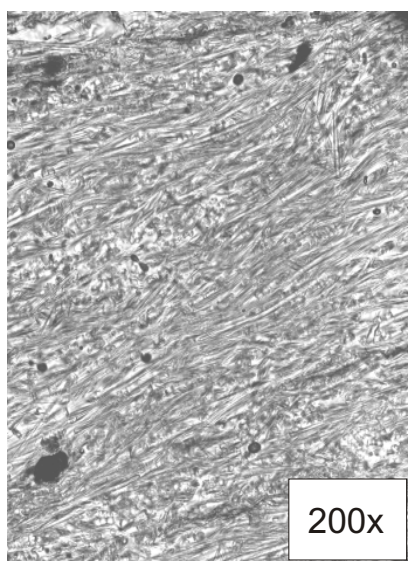

(E)

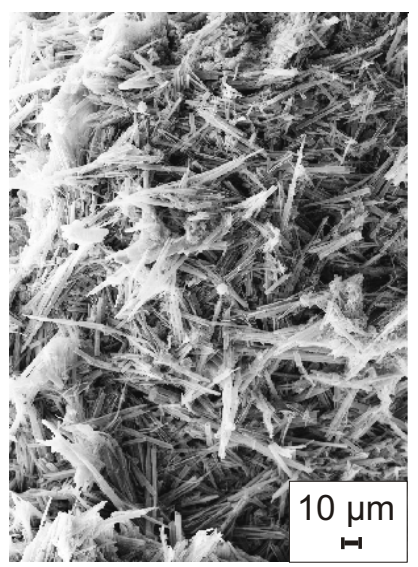

(F)

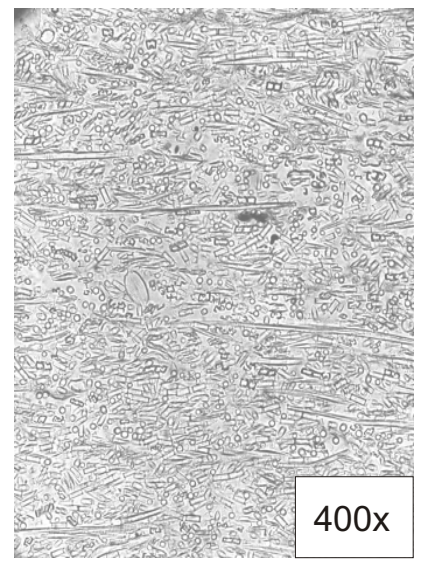

(G)

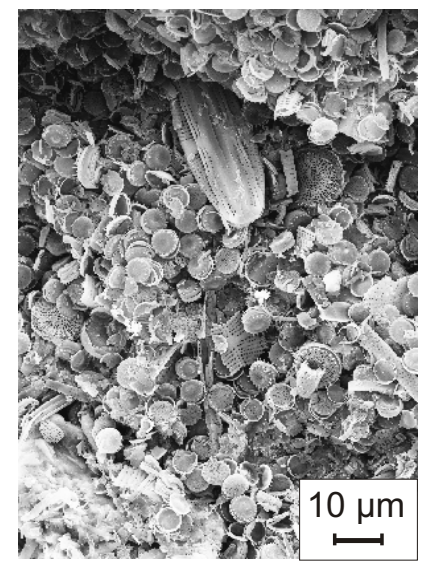

$(\mathrm{H})$

Fig. 3. Thin-section and scanning electron microscope photographs from different varve sub-layers from Dethlingen: (A, B) dark sublayer; (C, D) light sub-layer type A; (E, F) light sub-layer type B; (G, H) light sub-layer type C.

at the lake bottom, forming the light sub-layers. Stratification of the water column in summer led to anoxic bottom lake conditions facilitating the preservation of varves (e.g. O'Sullivan, 1983; Brauer, 2004). The deposition of diatom frustules, organic matter and other material from the littoral zone of the lake suggests the re-establishment of the lake circulation during the deposition of the dark sub-layers. The mixing of the water column can be attributed predominantly to an enhancement of wind and wave activity during autumn and early winter; in addition, the low content of clay particles in the dark sub-layers points to minor runoff from the catchment area into the lake during that time. The sharp boundary between the dark and succeeding light sub-layer suggests a transient break in sediment accumulation, which may be attributed to an ice-cover of the lake during winter. During that time, single wind-transported coarse silt and sand grains were trapped in the ice and deposited within the lake sediments after ice melting in spring. These dropstone-like sand grains additionally confirm the seasonal interpretation of the sub-layers. The above-mentioned characteristics suggest that the Dethlingen palaeolake was dimictic, ice-covered and stratified during parts of the year, and experienced periods of mixing between these two states (e.g. Lewis, 1983).

\subsection{Varve counting and thickness measurements}

In total, 2864 varves were counted between 27.93 and $33.68 \mathrm{mbs}$. For small-scale core intervals where varve preservation was poor or sediment had been disturbed during coring or laboratory processing, interpolations were performed based on the average thickness of 20 varves deposited directly below and above the respective interval. Based on these procedures, the floating chronology for the laminated diatomite at Dethlingen was calculated to comprise 3255 varve years.

The average varve thickness is $1.74 \mathrm{~mm}$ (Fig. 4). The thickness of the light sub-layers varies between 0.05 and $5 \mathrm{~mm}$ (average: $0.68 \mathrm{~mm}$ ), whereas the thickness of the dark sub-layers varies between 0.08 and $5 \mathrm{~mm}$ (average: $1.06 \mathrm{~mm}$ ) 


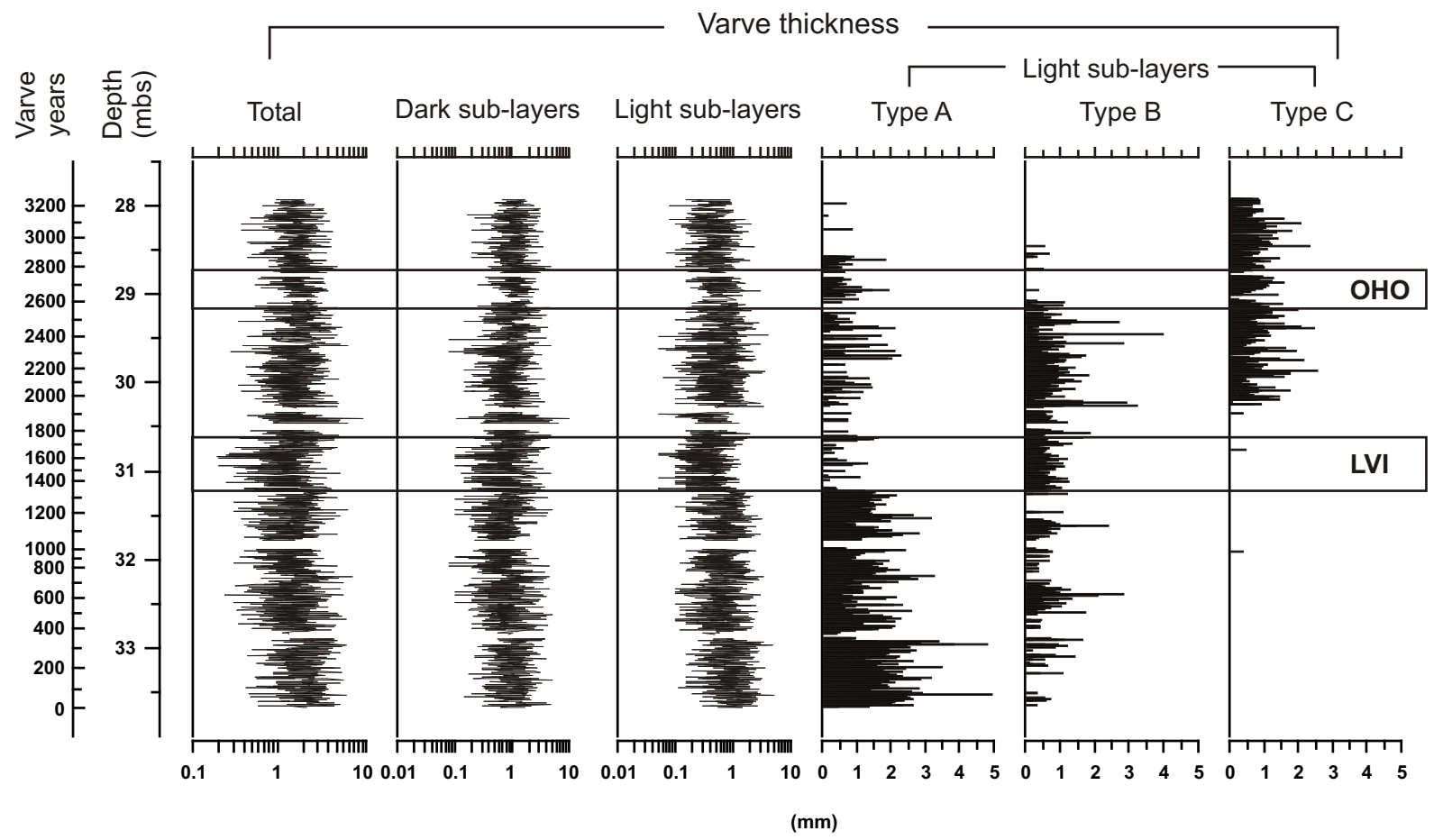

Fig. 4. Varve thickness measurements of dark sub-layers and different types of light sub-layers. Positions of the Older Holsteinian Oscillation $(\mathrm{OHO})$ and the Low Variability Interval (LVI) are indicated.

(Fig. 4). A qualitative distribution of different types of light sub-layers in the examined core interval was established based on the dominant diatom genera observed in the thin sections; Type-A is dominated by diatoms of the genera Stephanodiscus with a size of $>10 \mu \mathrm{m}$ (Fig. 3c, d), type- $\mathrm{B}$ is dominated by elongated diatoms of the genus Ulnaria (Fig. 3e, f), and type-C mainly comprises smallsized diatoms $(<10 \mu \mathrm{m})$ of the genera Aulacoseira and Stephanodiscus (Fig. 3g, h). In general, representatives of type-A are thicker (average: $0.87 \mathrm{~mm}$ ) than those of type$\mathrm{C}(0.54 \mathrm{~mm})$ and type-B $(0.52 \mathrm{~mm})$ (Fig. 4). The distribution of these light sub-layer types within the studied core interval documents a clear succession in diatom assemblages (Fig. 4). The light sub-layers from the lower interval of the laminated diatomite $(33.68-31.22 \mathrm{mbs})$ are dominated by large Stephanodiscus species (type-A) succeeded by $\mathrm{Ul}$ naria species (type-B) in the middle part (31.22-30.20 mbs), whereas the upper laminated interval $(30.20-27.93 \mathrm{mbs})$ is characterised by a prevalence of small Stephanodiscus and Aulacoseira species (type-C).

\subsection{Time series analyses}

The power spectra of the datasets for the light and dark sub-layers exhibit several peaks that exceed the $95 \%$ and $99 \%$ confidence levels (Fig. 5). Significant peaks occur at decadal-scale periods of $90,25,15$, and $10.5 \mathrm{yr}$, but also at sub-decadal-scale periods of $5.8-6.1,3-5$, and $2-3 \mathrm{yr}$.
Table 1. Summary of significant spectral peaks of light and dark sub-layer time series of the Dethlingen varves and their possible forcing mechanisms.

\begin{tabular}{lrrl}
\hline & $\begin{array}{r}\text { Light } \\
\text { sub-layers } \\
\text { spectriod }\end{array}$ & $\begin{array}{r}\text { Dark } \\
\text { sub-layers } \\
\text { spectra }\end{array}$ & Forcing \\
\hline 512 & $95 \%$ & $95 \%$ & Solar or ocean circulation \\
90 & $99 \%$ & $99 \%$ & Solar (88-yr Gleissberg cycle) \\
25 & $99 \%$ & $95 \%$ & Solar (22-yr Hale cycle) \\
15 & - & $95 \%$ & ENSO \\
10.5 & $99 \%$ & - & Solar (11-yr Schwabe cycle) \\
$5.8-6.1$ & - & $99 \%$ & NAO \\
$3-5$ & mainly 95\% & mainly 99\% & ENSO \\
$2-2.7$ & $99 \%$ & mainly 95\% & NAO/(QBO) \\
\hline
\end{tabular}

In addition, the wavelet spectra show a prominent cycle at $\sim 512 \mathrm{yr}$ for both the light and dark sub-layers (Fig. 6). In the following, we compare these signals with solar cycles and spatio-temporal modes of global climate variability, such as the El Niño-Southern Oscillation (ENSO), the North Atlantic Oscillation (NAO) and the Quasi-Biennial Oscillation (QBO), which are well known from analyses of modern instrumental climate data and the Holocene palaeoclimatic record (e.g. Stuiver and Braziunas, 1993; Mann and Park, 1994; Hoyt and Schatten, 1997; Wanner et al., 2001; Labitzke, 2005; Gray et al., 2010). 

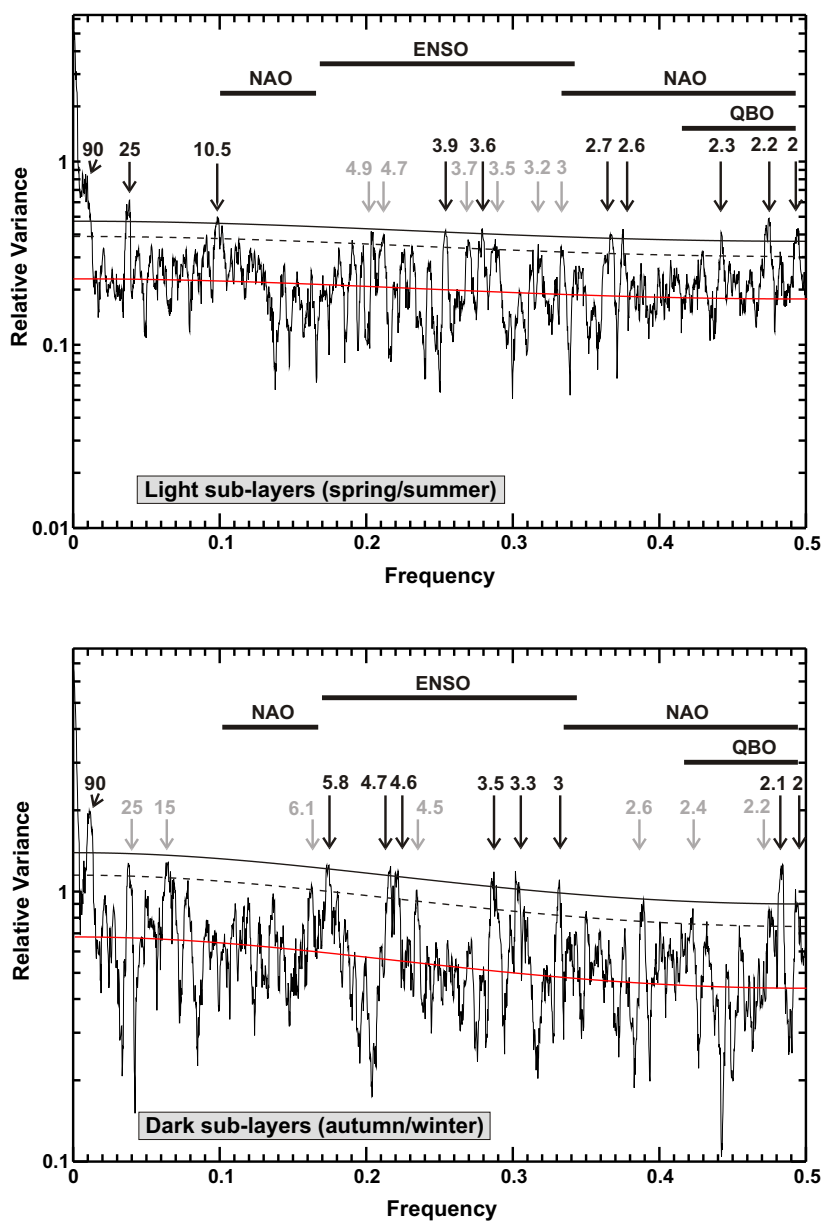

Fig. 5. Power spectra of the light and dark sub-layer thickness measurements. The red line indicates the median red noise; the dashed and solid black lines indicate the $95 \%$ and $99 \%$ confidence levels, respectively. El Niño-Southern Oscillation (ENSO), North Atlantic Oscillation (NAO), and Quasi-Biennial Oscillation (QBO) bandwidths are according to Mann and Park (1994).

\subsubsection{Solar-cyclicity-like variability}

Four peaks from the Dethlingen varve time series spectra can be correlated to known solar cycles (Fig. 5; Table 1). The most prominent, at $90 \mathrm{yr}$, can be attributed to the 88yr Gleissberg solar cycle (e.g. Gleissberg, 1944; Stuiver and Braziunas, 1993; Hoyt and Schatten, 1997) that has previously been recorded in several glacial (Anderson and Koopmans, 1963; Vos et al., 1997; Prasad et al., 2004) and interglacial varve time series (Anderson and Koopmans, 1963; Vos et al., 1997; Dean et al., 2002; Brauer et al., 2008). The 25- and 10.5-yr peaks from Dethlingen may correlate to the 22-yr Hale and 11-yr Schwabe solar cycles, respectively (e.g. Hoyt and Schatten, 1997) that have also been widely found in Quaternary varve time series of glacial (Anderson, 1961; Anderson and Koopmans, 1963; Vos et al., 1997; Rittenour et al., 2000) and interglacial origin (Anderson, 1961,
1992; Anderson and Koopmans, 1963; Zolitschka, 1992; Vos et al., 1997; Livingstone and Hajdas, 2001; Dean et al., 2002; Theissen et al., 2008). The statistically significant expression of all three prominent decadal-scale solar cycles makes the Dethlingen varve record unique because most known varve records only contain evidence for one or two of these cycles, probably because of insufficient sensitivity of each individual lake's sedimentological properties to record the solar magnetic modulation (e.g. Solanki et al., 2004; Muscheler et al., 2005) over certain time periods (e.g. Anderson, 1992).

In addition to these cycles, our record provides evidence for a centennial-scale cycle at $\sim 512 \mathrm{yr}$, which has been rarely detected in varve time series (Prasad et al., 2004; Brauer et al., 2008). To date, its origin remains unclear; it is considered to be related to either solar forcing (Stuiver et al., 1995; Sarnthein et al., 2003) or changes in the North Atlantic thermohaline circulation (Stuiver and Braziunas, 1993; Chapman and Shackleton, 2000; Damon and Peristykh, 2000; Risebrobakken et al., 2003). No other centennial-scale cycles were identified in the Dethlingen record, e.g. the 207yr Suess solar cycle (e.g. Hoyt and Schatten, 1997) that were previously recorded in varve time series (e.g. Anderson, 1992; Vos et al., 1997; O'Sullivan et al., 2002; Prasad et al., 2004; Brauer et al., 2008).

Because the solar-like cycles are evidenced in both light and dark sub-layer spectra, we argue that solar forcing influenced the lake sedimentation throughout the year. The light sub-layers at Dethlingen, which represent the primary lake productivity (see Sect. 3.1), are characterized by peaks of all three decadal-scale solar cycles (i.e. Gleissberg, Hale, and Schwabe cycles) at the $99 \%$ confidence level (Fig. 5). This suggests a significant solar influence on the biological productivity of the lake, most likely by affecting water mixing intensity, temperature, light and UV radiation that exert a strong control on algal productivity (e.g. Bothwell et al., 1994; Beer et al., 2000; Graham and Wilcox, 2000; Gray et al., 2010). The occurrence of solar-like cyclicity in the dark sub-layers, particularly the Gleissberg cycle (Fig. 5), points to solar influence on lake circulation during autumn and winter, most likely through atmospheric circulation changes that modulated wind and wave activity (see Sect. 3.1). Possible links between solar irradiance and atmospheric circulation have been attributed to the solar influence on stratospheric temperature that may modify zonal winds and storm tracks (e.g. Haigh, 1996; Carslaw et al., 2002; Gray et al., 2010).

Summarizing the above, the time series analysis of the Dethlingen varve record suggests a strong impact of solar cyclicity on the processes responsible for the seasonal sedimentation by influencing the lake's primary productivity and the atmospheric circulation over the study area.

\subsubsection{Variability within the ENSO/NAO band}

The Dethlingen varve record reveals significant variability at sub-decadal time scales, with signals exceeding the $95 \%$ 


\section{Light sub-layers (spring/summer)}

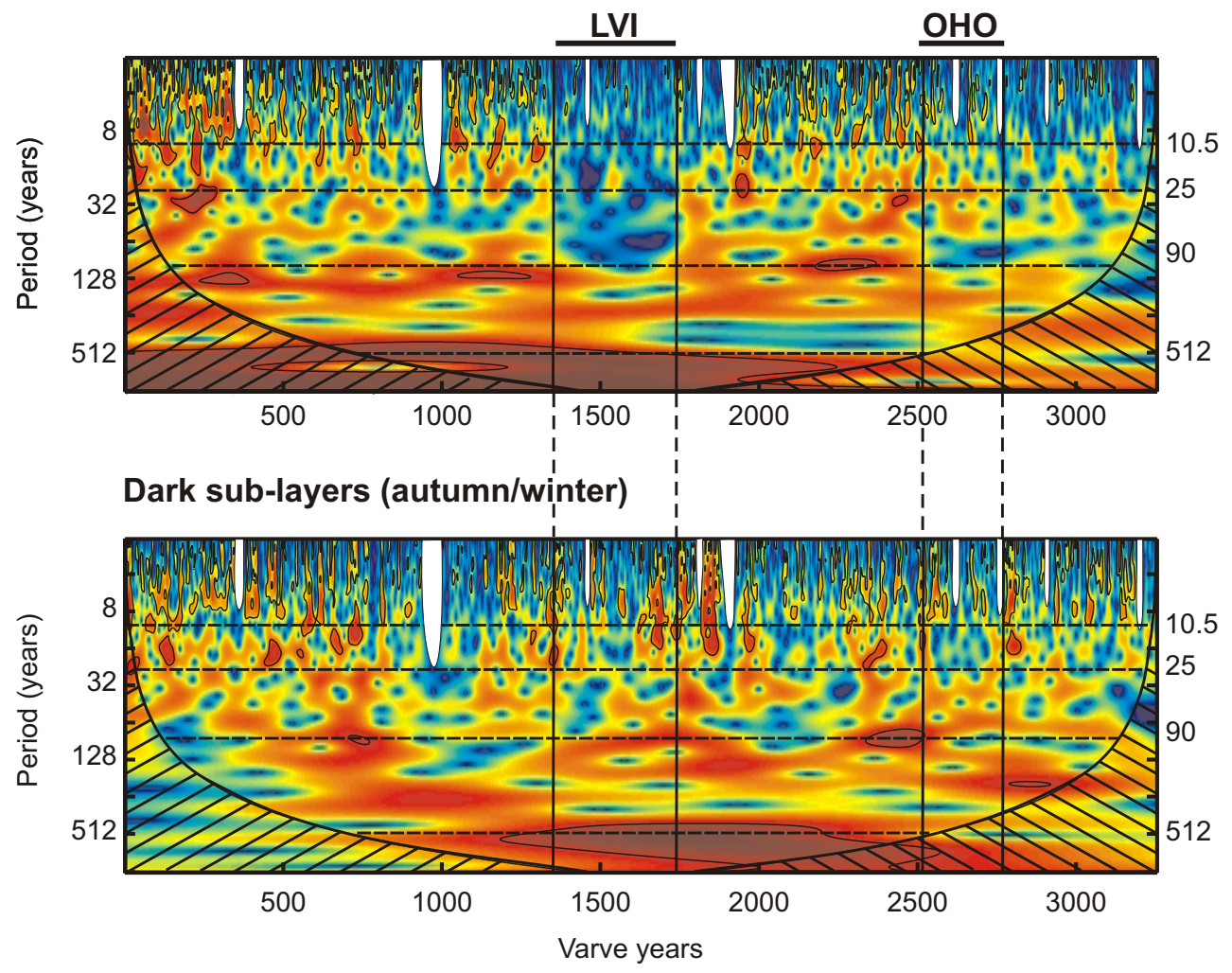

Fig. 6. Wavelet power spectra of the light and dark sub-layer thickness measurements. Wavelet amplitudes are colour coded from red (high power) to blue (low power). Contoured areas exceed the $95 \%$ confidence levels for a red noise background spectrum. Hatched areas indicate the cone of influence where wavelet analysis is affected by edge effects. Dashed lines mark the solar-like periodicities. White cones indicate intervals with no varve-thickness data. Positions of the Older Holsteinian Oscillation (OHO) and the Low Variability Interval (LVI) are indicated (see Sect. 3.4).

or $99 \%$ confidence levels grouped into three distinct bands, i.e. 2-2.7 yr, 3-5 yr, and 5.8-6.1 yr (Fig. 5; Table 1). Most of the significant peaks are recorded in the range of 3 to $5 \mathrm{yr}$ within the conventional ENSO bandwidth (Mann and Park, 1994; D' Arrigo et al., 2005). Variability within the ENSO bandwidth has been reported in lateglacial to recent varve sequences from North and South America (Rittenour et al., 2000; Nederbragt and Thurow, 2005; Fagel et al., 2008), but to date has not been clearly witnessed in varves from Europe. The ENSO is a natural mode of oscillation that results from unstable interactions between the tropical Pacific Ocean and the atmosphere, affecting weather and climate worldwide (e.g. Fedorov and Philander, 2000). A teleconnection between the Pacific region and Europe via the stratosphere allows the ENSO to influence European climate in late winter and spring (e.g. Brönnimann, 2007; Brönnimann et al., 2007; Ineson and Scaife, 2009). The signal in European climate comprises two modes: during El Niño conditions, when a reduction of coastal upwelling and an increase in sea-surface temperature along the western coast of tropical South America is observed in the equatorial Pacific, the European continent witnesses very low temperatures in NE Europe, increased precipitation in the northern Mediterranean region, and decreased precipitation in Norway. Reversed conditions are observed in Europe during La Niña conditions, which comprise the opposite mode of El Niño in the equatorial Pacific (e.g. Brönnimann, 2007). The cyclicity observed at Dethlingen is in agreement with modern weather observations from Europe that suggest an ENSO influence on climate every $3.5 \mathrm{yr}$ (Rodó et al., 1997). The ENSOlike variability is stronger expressed in the spectrum of the dark sub-layers, pointing to a pronounced ENSO impact on winter atmospheric circulation during the Holsteinian interglacial (Fig. 5).

The Dethlingen varve time series further shows significant variability at the margins of the ENSO bandwidth between 5.8 and 6.1 and between 2.4 and $2.6 \mathrm{yr}$ (Fig. 5). Although this variability may again represent an ENSO impact on varve formation, modern observational data suggest that these signals are better attributed to the NAO. The NAO, which represents a hemispheric meridional oscillation in atmospheric masses centered near Iceland and the subtropical Atlantic 

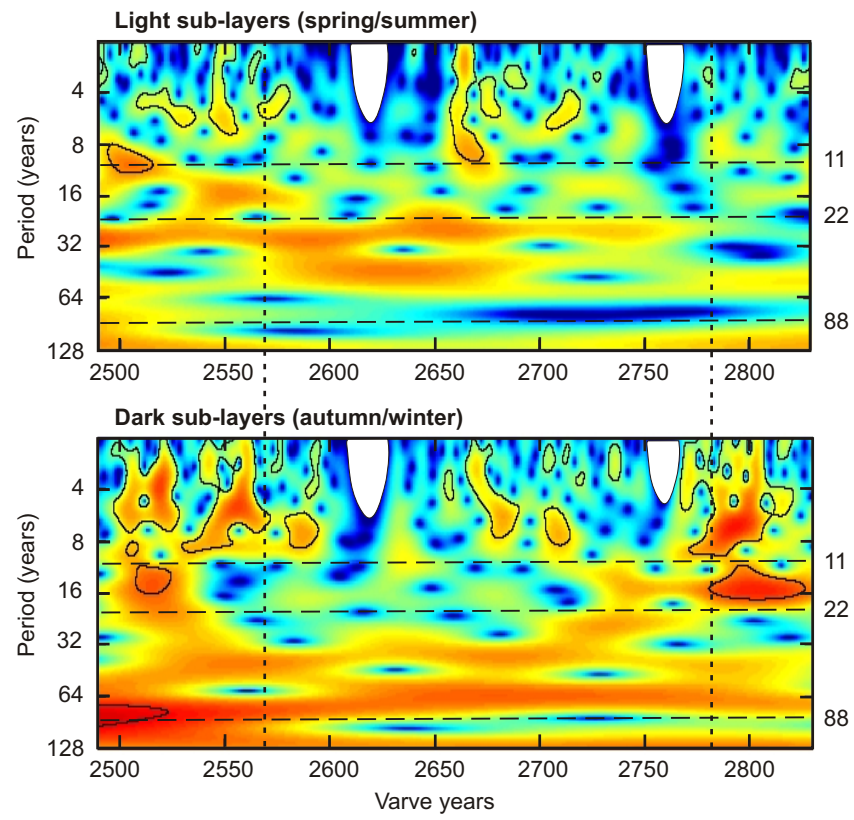

Fig. 7. Wavelet power spectra of the light and dark sub-layer thickness measurements spanning the $\mathrm{OHO}$ interval. Wavelet amplitudes are colour coded from red (high power) to blue (low power). Contoured areas exceed the $95 \%$ confidence levels for a red noise background spectrum. Vertical dashed lines mark the boundaries of the $\mathrm{OHO}$ at 2565 and 2782 varve years. Horizontal dashed lines indicate the solar-like periodicities. White cones indicate intervals with no varve-thickness data.

Ocean, affects European climate particularly in boreal winter from December through March (e.g. Hurrell, 1995; Visbeck et al., 2001; Wanner et al., 2001). The NAO is characterized by a positive mode related to warmer and wetter than average conditions in north Europe and colder and drier conditions in the Mediterranean region, and a negative mode with reversed characteristics. The NAO variability occurs at bandwidths of 2.5-3 and 6-10 yr (e.g. Appenzeller et al., 1998; Hurrell and van Loon, 1997; Pozo-Vásquez et al., 2000). Varve time series from central and western Europe have also reported significant peaks at 6.1-6.2 yr during the Holocene (Livingstone and Hajdas, 2001; O'Sullivan et al., 2002), whereas a similar period at $6.6 \mathrm{yr}$ has been recorded on oxygen isotope variations of calcite varves from the southern Alps during MIS 11 (Mangili et al., 2010). It therefore seems that the $\sim 6 \mathrm{yr}$ signal documented in European varve sequences represents NAO-like variability rather than ENSO-like variability because the latter is generally more pronounced in the $3-5 \mathrm{yr}$ bandwidth (Mann and Park, 1994). Further evidence for a NAO-like variability in the Holsteinian record from Dethlingen is provided by the fact that the $\sim 6 \mathrm{yr}$ signal is only evident in the spectrum from the dark sub-layers. It therefore reflects sedimentation processes during autumn/winter, which is in good agreement with the seasonal impact of the NAO on European climate as known from the Recent (e.g. Hurrell,
1995; Visbeck et al., 2001; Wanner et al., 2001). The variability between 2 and $2.7 \mathrm{yr}$ may be attributed to either the NAO or the QBO (Mann and Park, 1994). The QBO is one of the most commonly recorded circulation patterns in modern data, comprising a variability of the equatorial stratosphere expressed by an alternation in the downward propagation of easterly and westerly wind regimes (e.g. Baldwin et al., 2001). Although such periodicities commonly occur in varved sequences, these signals should be interpreted with caution because of their proximity to the 2-yr Nyquist frequency of annual sampling (e.g. Weedon, 2003).

Finally, the spectrum for the dark sub-layers exhibits a periodicity of $15 \mathrm{yr}$ exceeding the $95 \%$ confidence level (Fig. 5). Such a periodicity has been previously noticed in Central Europe during the Holocene and MIS 11, although its forcing has remained unclear (Livingstone and Hajdas, 2001; Mangili et al., 2010). We suggest that this $15-\mathrm{yr}$ cycle may be related to the interdecadal ENSO variability at 15-18 yr (Mann and Park, 1994). This interpretation is further corroborated by modern observations from Iberia that demonstrate the existence of an amplified ENSO signal at 14.2 yr, i.e. after every four ENSO events (Rodó et al., 1997).

To summarize, the Dethlingen varve time series indicates significant sub-decadal climate variability in European climate during MIS 11, which may be attributed to ENSOand NAO-like climate modes. The pronounced signals in the spectrum of the dark sub-layers point to a strong influence of the ENSO/NAO-like variability especially on winter climate, possibly through changes in atmospheric circulation that influenced lake mixing and the duration of ice cover.

\subsection{Variability of varve thickness through time}

The sub-decadal- and decadal-scale cyclicity as described in Sects. 3.3.1 and 3.3.2 is evidenced in most parts of the Dethlingen record (Fig. 6). However, a close inspection of the wavelet spectra for the light and dark sub-layers reveals distinct intervals where this cyclicity appears only in one of the two spectra or is discontinuous in both spectra.

An example for the first case is a 430-yr-long interval between 1320 and 1750 varve years (Fig. 6). This interval, hereafter named low-variability interval (LVI), is marked by a strong sub-decadal and decadal cyclicity in the dark sub-layer spectrum and a very weak cyclicity in the light sub-layer spectrum. We therefore hypothesize that although the spectrum for the dark sub-layers points to an external cyclical forcing influencing the Dethlingen palaeolake system, changes in the boundary conditions (e.g. nutrients, water level) during spring and summer precluded the recording of this forcing in the light sub-layer spectrum. To test this hypothesis, we take a closer look at the varve microfacies during the LVI. The onset of the LVI coincides with a major change in the spring-blooming diatom assemblages accompanied by a thinning of the light sub-layers (Fig. 4). In particular, the diatoms dominating the light sub-layers change 


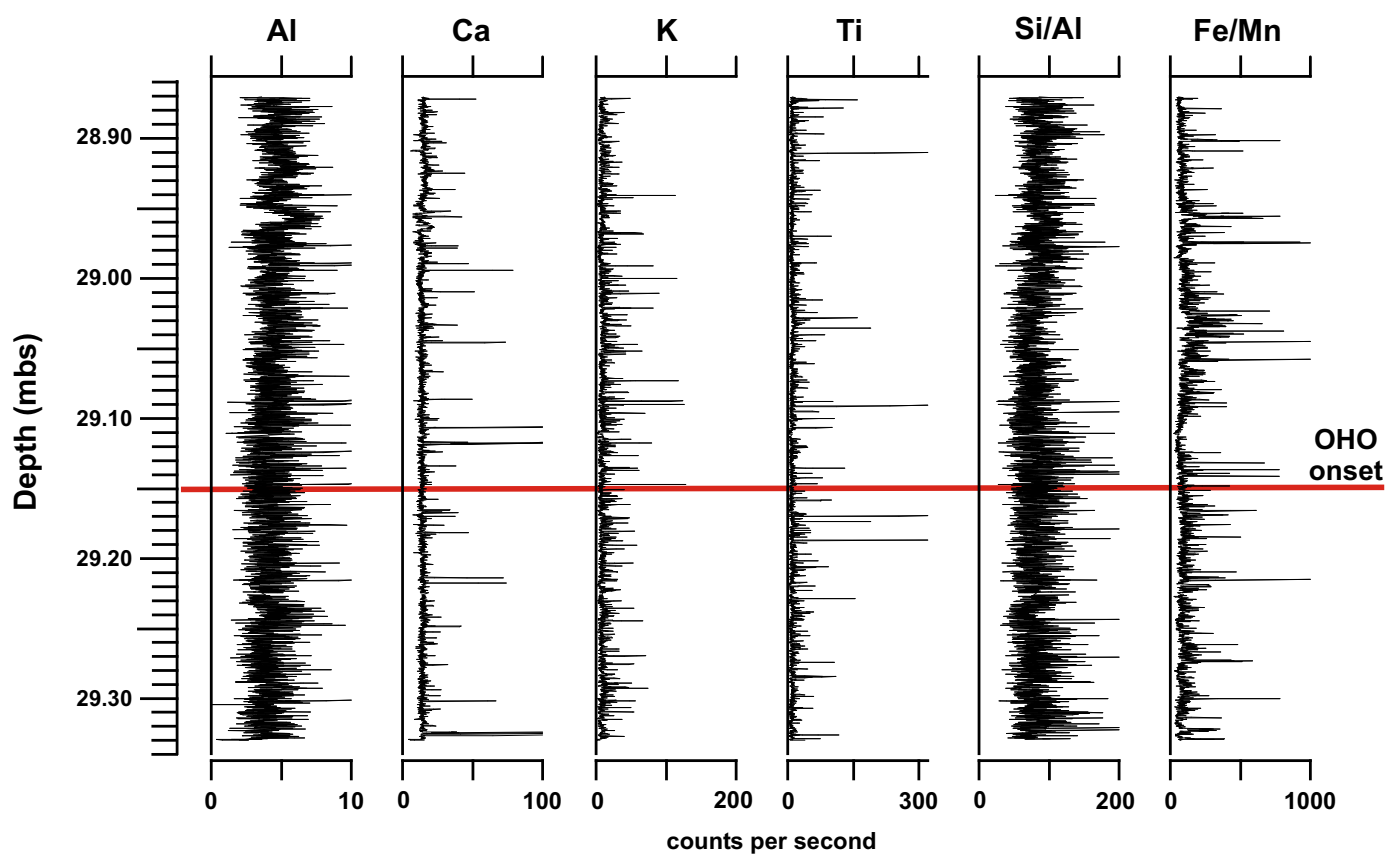

Fig. 8. Geochemical results of $\mu$-XRF (step size: $100 \mu \mathrm{m}$ ) spanning $\sim 90 \mathrm{yr}$ before the onset and $\sim 150 \mathrm{yr}$ into the Older Holsteinian Oscillation $(\mathrm{OHO})$. The position of the $\mathrm{OHO}$ is defined by a strong and abrupt decline of temperate tree taxa percentages in the Dethlingen core (Koutsodendris et al., 2010).

from Stephanodiscus $(>10 \mu \mathrm{m})$ to Ulnaria species, the latter requiring a higher $\mathrm{Si}$ P ratio (e.g. Kilham et al., 1986; Kirilova et al., 2008). It appears likely that the compositional change in diatom assemblages during this interval was caused by a weakening of the spring circulation, thereby decreasing the phosphorus transport from the hypolimnion to the photic zone to the benefit of diatoms that require high $\mathrm{Si}: \mathrm{P}$ ratio to grow. The lake circulation during this interval may have been modified by changes in atmospheric circulation. As a result, the boundary conditions of the Dethlingen palaeolake were seasonally modified, precluding the light sub-layers to record external forcing. The sedimentation processes became susceptible to the recording of external forcing again when the lake system returned to conditions that supported a stronger blooming of Stephanodiscus species (Fig. 4).

A good example of the second case, i.e. when the spectra of both the light and dark sub-layers do not show variability, is the interval between 2564 and 2782 varve years (29.15 to $28.73 \mathrm{mbs}$; Fig. 7) that coincides with the prominent OHO event (e.g. Müller, 1974; Kukla, 2003; Koutsodendris et al., 2010; Koutsodendris, 2011). Across the OHO, the wavelet spectra of both the light and dark sub-layers do not show any statistically significant indication for the 11yr Schwabe cycle; moreover, there is a strong weakening of the 22- and 88-yr solar cycles (Fig. 7). In addition, the ENSO/NAO-like sub-decadal variability almost ceases with the onset of the $\mathrm{OHO}$ and only recovers again after the end of the event (Fig. 7). Following a similar concept as for the LVI, the absence of short-term variability during the OHO may be explained by seasonal changes in the boundary conditions of the Dethlingen palaeolake. In particular, the composition of the light sub-layers shifts from Ulnaria-dominated to Stephanodiscus-dominated sub-layers with the onset of the $\mathrm{OHO}$, suggesting changes in lake mixing and productivity (Fig. 4). However, the observations from thin sections do not support a scenario of seasonal changes in the dark sub-layers. On top of that, $\mu$-XRF data spanning $\sim 90 \mathrm{yr}$ before the onset and $\sim 150 \mathrm{yr}$ into the OHO (29.33 to $28.87 \mathrm{mbs})$ do not yield evidence for significant modifications in the geochemical signal to support changes in the sedimentation processes during autumn/winter (Fig. 8). In particular, the intensities of minerogenic-detrital indicator elements (such as $\mathrm{Al}, \mathrm{Ca}$, $\mathrm{K}, \mathrm{Ti}$ ) and the $\mathrm{Si} / \mathrm{Al}$ ratio remain rather constant, suggesting no significant change in terrestrial input. In addition, the constant Fe/Mn ratio does not support any oxygenation changes at the bottom of the lake. We therefore suggest that the absence of cyclical signals in the varves during the $\mathrm{OHO}$ points to a weakening of the external forcing. If correct, this implies that both the solar activity and ENSO/NAO-like variability were strongly weakened during this period. An alternative explanation could be a weak sensitivity of the climate system to the external forcing during the OHO.

It has been suggested that the triggering mechanism of the OHO may be similar to the $8.2 \mathrm{ka}$ BP event, with a cooling caused by a transient slowdown in North Atlantic 
circulation leading to a turnover in central European vegetation (Koutsodendris et al., 2010; Koutsodendris, 2011). Based on the Dethlingen time series analysis, it also appears possible that this climate oscillation is further related to lower solar irradiation. This may also have modified sub-decadal climate variability, as it has been suggested for prominent climate oscillations of the present interglacial, i.e. the $8.2 \mathrm{ka}$ event (e.g. Muscheler et al., 2004; Rohling and Pälike, 2005) and the Little Ice Age (e.g. Shindell et al., 2001).

The two cases of discontinuous short-term climate variability in certain intervals as evidenced in the Dethlingen varve record highlight the need to apply time series analysis to the seasonal sub-layers thickness measurements. When indications of short-term cyclicities are absent in certain intervals of one of the seasonal sub-layer spectra but present in the same intervals of the other seasonal spectra, the processes involved in varve formation were obviously susceptible to record agents of external forcing only under specific boundary conditions. In contrast, when the cyclic signals are absent from all seasonal spectra, the external climate forcing controlling varve formation was either weakened and/or ceased completely or, alternatively, the climate system was not sensitive to the external forcing during these periods.

\section{Conclusions}

Microfacies and time series analyses from an annually laminated sedimentary archive of the Holsteinian interglacial (MIS 11) yield a strong signal of natural cyclicity at decadal and sub-decadal time scales. The decadal-scale cyclicity is attributed to solar forcing that may have influenced the sedimentation of the light varve sub-layers (spring/summer) by driving changes in the productivity of the palaeolake. The sub-decadal-scale cyclicity is attributed to ENSO and NAO climate modes, predominantly influencing the dark sub-layer formation (autumn/winter) through changes in atmospheric circulation that affected lake mixing. Our analyses clearly demonstrate that in order to interpret the signals of varve time series analysis and to correlate them with temporal modifications of the external climate forcing, it is essential to (a) understand the sedimentological processes controlling varve formation and to (b) compare the results of individually analyzed seasonal sub-layer-thickness datasets.

The solar- and ENSO/NAO-like natural cyclicity during MIS 11 as recorded in the $\sim 3200$-yr-long varve time series from Dethlingen is closely comparable with the central European climate variability of the present interglacial. This suggests that the short-term climate cyclicity during the two interglacials is controlled by similar forcing. Taking this observation a step further, we suggest that MIS 11, besides the well-established long-term astronomical analogy, may be regarded as a good analogue for the Holocene with regard to short-term (sub-decadal- to decadal-) timescales. As a result, understanding the short-term climate variability during MIS
11 may potentially contribute to simulate future climate evolution of the present interglacial.

Acknowledgements. Discussions with C. Mangili, W. Oschmann and B. van de Schootbrugge, and technical support by D. Berger, H. Kemnitz, M. Köhler, J. Mingram, J. Parker, and B. Richert are gratefully acknowledged. We thank two anonymous referees for their positive and constructive reviews. This study was funded by the German Research Foundation (DFG; grant MU 1715-2) and the Biodiversity and Climate Research Center (BIK-F) of the Hessian Initiative for Scientific and Economic Excellence (LOEWE).

Edited by: G. M. Ganssen

\section{References}

Alley, R. B., Marotzke, J., Nordhaus, W. D., Overpeck, J. T., Peteet, D. M., Pielke, R. A. Jr., Pierrehumbert, R. T., Rhines, P. B., Stocker, T. F., Talley, L. D., and Wallace, J. M.: Abrupt climate change, Science, 299, 2005-2010, doi:10.1126/science.1081056, 2003.

Anderson, R. Y.: Solar-terrestrial climatic patterns in varved sediments, Ann. N. Y. Acad. Sci., 95, 424-439, doi:10.1111/j.17496632.1961.tb50048.x, 1961.

Anderson, R. Y.: Possible connection between surface winds, solar activity and the Earth's magnetic field, Nature, 358, 51-53, doi:10.1038/358051a0, 1992.

Anderson, R. Y. and Koopmans, L. H.: Harmonic analysis of varve time series, J. Geophys. Res., 68, 877-893, doi:10.1029/JZ068i003p00877, 1963.

Appenzeller, C., Stocker, T. F., and Anklin, M.: North Atlantic Oscillation dynamics recorded in Greenland ice cores, Science, 282, 446-449, doi:10.1126/science.282.5388.446, 1998.

Baldwin, M. P., Gray, L.J., Dunkerton, T. J., Hamilton, K., Haynes, P. H., Randel, W. J., Holton, J. R., Alexander, M. J., Hirota, I., Horinouchi, T., Jones, D. B. A., Kinnersley, J. S., Marquardt, C., Sato, K., and Takahashi, M.: The Quasi-Biennial Oscillation, Rev. Geophys., 39, 179-229, doi:10.1029/1999RG000073, 2001.

Beer, J., Mende, W., and Stellmacher, R.: The role of sun in climate forcing, Quaternary Sci. Rev., 19, 403-415, doi:10.1016/S02773791(99)00072-4, 2000.

Benda, L. and Brandes, H.: Die Kieselgur-Lagerstätten Niedersachsens. I. Verbreitung, Alter und Genese, Geol. Jahrb. A, 21, 3-85, 1974.

Benda, L., Hofmeister, E., Mielke, K., and Müller, H.: Die Kieselgur-Lagerstätten Niedersachsens III. Neue Prospektionsergebnisse (Lagerstätte Dethlingen), Geol. Jahrb. A, 75, 585609, 1984.

Berger, A. and Loutre, M. F.: An exceptionally long interglacial ahead? Science, 297, 1287-1288, doi:10.1126/science.1076120, 2002.

Bothwell, M. L., Darren, M. J. S., and Pollock, C. M.: Ecosystem response to solar ultraviolet-B radiation: Influence of trophic-level interactions, Science, 265, 97-100, doi:10.1126/science.265.5168.97, 1994.

Brauer, A.: Annually laminated lake sediments and their palaeoclimatic relevance, in: The climate in historical times, edited by: Fisher, H., Kumke, T., Lohmann, G., Flöser, G., Miller, H., 
von Storch, H., and Negendank, J. F. W., Towards a synthesis of Holocene proxy data and climate models, Springer Verlag, 111129, 2004.

Brauer, A., Endres, C., Günter, C., Litt, T., Stebich, M., and Negendank, J. F. W.: High resolution sediment and vegetation responses to Younger Dryas climate change in varved lake sediments from Meerfelder Maar, Germany, Quaternary Sci. Rev., 18, 321-329, doi:10.1016/S0277-3791(98)00084-5, 1999a.

Brauer, A., Endres, C., and Negendank, J. F. W.: Lateglacial calendar year chronology based on annually laminated sediments from Lake Meerfelder Maar, Germany, Quatern. Int., 61, 17-25, doi:10.1016/S1040-6182(99)00014-2, 1999b.

Brauer, A., Allen, J. R. M., Mingram, J., Dulski, P., Wulf, S., and Huntley, B.: Evidence for last interglacial chronology and environmental change from Southern Europe, P. Natl. Acad. Sci. USA, 104, 450-455, doi:10.1073/pnas.0603321104, 2007.

Brauer, A., Mangili, C., Moscariello, A., and Witt, A.: Palaeoclimatic implications from micro-facies data of a 5900 varve time series from the Piànico interglacial sediment record, Southern Alps, Palaeogeogr. Palaeocl., 259, 121-135, doi:10.1016/j.palaeo.2007.10.003, 2008.

Brönnimann, S.: Impact of El Niño - Southern Oscillation on European climate, Rev. Geophys., 45, RG3003, doi:10.1029/2006RG000199, 2007.

Brönnimann, S., Xoplaki, E., Casty, C., Pauling, A., and Luterbacher, J.: ENSO influence on Europe during the last centuries, Clim. Dynam., 28, 181-197, doi:10.1007/s00382-006-0175-z, 2007.

Carslaw, K. S., Harrison, R. G., and Kirkby, J.: Cosmic rays, clouds, and climate, Science, 298, 1732-1737, doi:10.1126/science.1076964, 2002.

Chapman, M. R. and Shackleton, N. J.: Evidence of 550year and 1000-year cyclicities in North Atlantic circulation patterns during the Holocene, Holocene, 10, 287-291, doi:10.1191/095968300671253196, 2000.

D’ Arrigo, R., Cook, E. R., Wilson, R. J., Allan, R., and Mann, M. E.: On the variability of ENSO over the past six centuries, Geophys. Res. Lett., 32, L03711, doi:10.1029/2004GL022055, 2005.

Damon, P. E. and Peristykh, A. N.: Radiocarbon calibration and application to geophysics, solar physics, and astrophysics, Radiocarbon, 42, 137-150, 2000.

de Abreu, L., Abrantes, F. F., Shackleton, N., Tzedakis, P. C., McManus, J. F., Oppo, D. W., and Hall, M. A.: Ocean climate variability in the eastern North atlantic during interglacial marine isotope stage 11: A partial analogue to the Holocene? Paleoceanography, 20, PA3009, doi:10.1029/2004PA001091, 2005.

de Beaulieu, J.-L., Andrieu-Ponel, V., Reille, M., Grüger, E., Tzedakis, P. C., and Svobodova, H.: An attempt at correlation between the Velay pollen sequence and the Middle Pleistocene stratigraphy from central Europe, Quaternary Sci. Rev., 20, 1593-1602, doi:10.1016/S0277-3791(01)00027-0, 2001

Dean, W., Anderson, R., Bradbury, J. P., and Anderson, D.: A 1500year record of climatic and environmental change in Elk Lake, Minnesota I: Varve thickness and gray-scale density, J. Paleolimnol., 27, 287-299, doi:10.1023/A:1016062207440, 2002.

Desprat, S., Sánchez-Goñi, M. F., Turon, J.-L., McManus, J. F., Loutre, M. F., Duprat, J., Malaize, B., Peyron, O., and Peypouquet, J.-P.: Is vegetation responsible for glacial inception during periods of muted insolation changes? Quaternary Sci. Rev., 24, 1361-1374, doi:10.1016/j.quascirev.2005.01.005, 2005.

Ehlers, J., Meyer, K.-D., and Stephan, H.-J.: The pre-Weichselian glaciations of North-West Europe. Quaternary Sci. Rev., 3, 1-40, doi:10.1016/0277-3791(84)90003-9, 1984.

Fagel, N., Boës, X., and Loutre, M. F.: Climate oscillations evidenced by spectral analysis of Southern Chilean lacustrine sediments: the assessment of ENSO over the last 600 years, J. Paleolimnol., 39, 253-266, doi:10.1007/s10933-007-9116-z, 2008.

Fedorov, A. V. and Philander, S. G.: Is El Niño changing? Science, 288, 1997-2002, doi:10.1126/science.288.5473.1997, 2000.

Geyh, M. A. and Müller, H.: Numerical ${ }^{230} \mathrm{Th} / \mathrm{U}$ dating and a palynological review of the Holsteinian/Hoxnian interglacial, Quaternary Sci. Rev., 24, 1861-1872, doi:10.1016/j.quascirev.2005.01.007, 2005.

Gleissberg, W.: A table of secular variations of the solar cycle, Terrestrial Magnetism and Atmospheric Electricity, 49, 243-244, doi:10.1029/TE049i004p00243, 1944.

Graham, L. E. and Wilcox, L. W.: Algae, Prentice Hall, USA, 2000.

Gray, L. J., Beer, J., Geller, M., Haigh, J. D., Lockwood, M., Matthes, K., Cubasch, U., Fleitmann, D., Harrison, G., Hood, L., Luterbacher, J., Meehl, G. A., Shindell, D., van Geel, B., and White, W.: Solar influences on climate, Rev. Geophys., 48, RG4001, doi:10.1029/2009RG000282, 2010.

Haigh, J. D.: The impact of solar variability on climate, Science, 272, 981-984, doi:10.1126/science.272.5264.981, 1996.

Helmke, J. P., Bauch, H. A., Röhl, U., and Kandiano, E. S.: Uniform climate development between the subtropical and subpolar Northeast Atlantic across marine isotope stage 11, Clim. Past, 4, 181-190, doi:10.5194/cp-4-181-2008, 2008.

Hoyt, D. V. and Schatten, K. H.: The role of the sun in climate change, Oxford University Press, UK, 1997.

Hurrell, J. W.: Decadal trends in the North Atlantic oscillation: Regional temperatures and precipitation, Science, 269, 676-679, doi:10.1126/science.269.5224.676, 1995.

Hurrell, J. W. and van Loon, H.: Decadal variations in climate associated with the North Atlantic Oscillation, Climatic Change, 36, 301-326, doi:10.1023/A:1005314315270, 1997.

Ineson, S. and Scaife, A. A.: The role of the stratosphere in the European climate response to El Niño, Nat. Geosci., 2, 32-36, doi:10.1038/ngeo381, 2009.

Jones, P. D. and Mann, M. E.: Climate over past millennia, Rev. Geophys., 42, RG2002, doi:10.1029/2003RG000143, 2004.

Kilham, P., Kilham, S. S., and Hecky, R. E.: Hypothesized resource relationships among African planktonic diatoms, Limnol. Oceanogr., 31, 1169-1181, 1986.

Kirilova, E. P., Bluszcz, P., Heiri, O., Cremer, H., Ohlendorf, C., Lotter, A. F., and Zolitschka, B.: Seasonal and interannual dynamics of diatom assemblages in Sacrower See (NE Germany): a sediment trap study, Hydrobiologia, 614, 159-170, doi:10.1007/s10750-008-9504-z, 2008.

Koutsodendris, A.: The Holsteinian interglacial (MIS 11c) as a palaeoclimatic analogue to the Holocene: Comparison of climate and ecosystem variability, $\mathrm{PhD}$ thesis, Goethe University Frankfurt, 139 pp., 2011.

Koutsodendris, A., Müller, U. C., Pross, J., Brauer, A., Kotthoff, U., and Lotter, A. F.: Vegetation dynamics and climate variability during the Holsteinian interglacial based on a pollen record from Dethlingen (northern Germany), Quaternary Sci. Rev., 29, 3298- 
3307, doi:10.1016/j.quascirev.2010.07.024, 2010.

Krupiński, K. M.: Pollen stratigraphy and succession of vegetation during the Mazovian interglacial, Acta Geographica Lodzensis, 70, 1-200, 1995.

Kukla, G.: Continental records of MIS 11, in: Earth's climate and orbital eccentricity; the marine isotope stage 11 question, edited by: Droxler, A. W., Poore, R. Z., and Burckle, L. H., AGU Geophysical Monograph Series, 137, 207-212, 2003.

Labitzke, K.: On the Solar cycle-QBO-relationship: A summary, J. Atmos. Sol.-Terr. Phy., 67, 45-54, doi:10.1016/j.jastp.2004.07.016, 2005.

Lewis, W. M.: A revised classification of lakes based on mixing, Can. J. Fish. Aquat. Sci., 40, 1779-1787, doi:10.1139/f83-207, 1983.

Livingstone, D. M. and Hajdas, I.: Climatically relevant periodicities in the thickness of biogenic carbonate varves in Soppensee, Switzerland (9740-6870 calendar yr BP), J. Paleolimnol., 25, 17-24, doi:10.1023/A:1008131815116, 2001.

Lotter, A. F.: Evidence of annual layering in Holocene sediments of Soppensee, Switzerland, Aquat. Sci., 51, 19-30, doi:10.1007/BF00877778, 1989.

Lotter, A. F. and Birks, H. J. B.: The separation of the influence of nutrients and climate on the varve time-series of Baldeggersee, Switzerland, Aquat. Sci., 59, 362-375, doi:10.1007/BF02522364, 1997.

Lotter, A. F. and Lemcke, G.: Methods for preparing and counting biochemical varves, Boreas, 28, 243-252, doi:10.1111/j.15023885.1999.tb00218.x, 1999.

Loutre, M. F. and Berger, A.: Marine Isotope Stage 11 as an analogue for the present interglacial, Global Planet. Change, 36, 209-217, doi:10.1016/S0921-8181(02)00186-8, 2003.

Mangili, C., Brauer, A., Moscariello, A., and Naumann, R.: Microfacies of detrital event layers deposited in Quaternary varved lake sediments of the Piànico-Sèllere Basin (northern Italy), Sedimentology, 52, 927-943, doi:10.1111/j.1365-3091.2005.00717.x, 2005 .

Mangili, C., Brauer, A., Plessen, B., and Moscariello, A.: Centennial-scale oscillations in oxygen and carbon isotopes of endogenic calcite from a 15,500 varve year record of the Piànico interglacial, Quaternary Sci. Rev., 26, 1725-1735, doi:10.1016/j.quascirev.2007.04.012, 2007.

Mangili, C., Plessen, B., Wolff, C., and Brauer, A.: Climatic implications of annual to decadal stable isotope data from calcite varves of the Piànico interglacial lake record, Southern Alps, Global Planet. Change, 71, 168-174, doi:10.1016/j.gloplacha.2010.01.027, 2010.

Mann, M. E. and Lees, J. M.: Robust estimation of background noise and signal detection in climatic time series, Climatic Change, 33, 409-445, doi:10.1007/BF00142586, 1996.

Mann, M. E. and Park, J.: Global-scale modes of surface temperature variability on interannual to century timescales, J. Geophys. Res., 99, 25819-25833, doi:10.1029/94JD02396, 1994.

McManus, J. F., Oppo, D., Cullen, J., and Healey, S.: Marine isotope stage 11 (MIS 11); Analogue for Holocene and future climate? in: Earth's Climate and Orbital Eccentricity; the Marine Isotope Stage 11 Question, edited by: Droxler, A. W., Poore, R. Z., and Burckle, L.H., AGU Geophysical Monograph Series 137, 69-85, 2003.

Müller, H.: Pollenanalytische Untersuchungen und Jahress- chichtenzählungen an der holstein-zeitlichen Kieselgur von Munster-Breloh, Geol. Jahrb. A, 21, 107-140, 1974.

Müller, U. C. and Pross, J.: Lesson from the past: present insolation minimum holds potential for glacial inception, Quaternary Sci. Rev., 26, 3025-3029, doi:10.1016/j.quascirev.2007.10.006, 2007.

Muscheler, R., Beer, J., and Vonmoos, M.: Causes and timing of the $8200 \mathrm{yr}$ BP event inferred from the comparison of the GRIP ${ }^{10} \mathrm{Be}$ and the tree ring $\Delta^{14} \mathrm{C}$ record, Quaternary Sci. Rev., 23, 2101-2111, doi:10.1016/j.quascirev.2004.08.007, 2004.

Muscheler, R., Joos, F., Müller, S. A., and Snowball, I.: How unusual is today's solar activity?, Nature, 436, E3-E4, doi:10.1038/nature04045, 2005.

Nederbragt, A. J. and Thurow, J.: Amplitude of ENSO cycles in the Santa Barbara Basin, off California, during the past 15000 years, J. Quaternary Sci., 20, 447-456, doi:10.1002/jqs.946, 2005.

Nitychoruk, J., Bińka, K., Hoefs, J., Ruppert, H., and Schneider, J.: Climate reconstruction for the Holsteinian Interglacial in eastern Poland and its comparison with isotopic data from Marine Isotope Stage 11, Quaternary Sci. Rev., 24, 631-644, doi:10.1016/j.quascirev.2004.07.023, 2005.

Nitychoruk, J., Bińka, K., Ruppert, H., and Schneider, J.: Holsteinian interglacial = Marine Isotope Stage 11?, Quaternary Sci. Rev., 25, 2678-2681, doi:10.1016/j.quascirev.2006.07.004, 2006.

O'Sullivan, P. E.: Annually-laminated lake sediments and the study of Quaternary environmental changes - A review, Quaternary Sci. Rev., 1, 245-313, doi:10.1016/0277-3791(83)90008-2, 1983.

O'Sullivan, P. E., Moyeed, R., Cooper, M. C., and Nicholson, M. J.: Comparison between instrumental, observational and high resolution proxy sedimentary records of Holocene climatic change - a discussion of possibilities, Quatern. Int., 88, 27-44, doi:10.1016/S1040-6182(01)00071-4, 2002.

Pozo-Vásquez, D., Esteban-Parra, M. J., Rodrigo, F. S., and CastroDíez, Y.: An analysis of the variability of the North Atlantic Oscillation in the time and frequency domain, Int. J. Climatol., 20, 1675-1692, 2000.

Prasad, S., Vos, H., Negendank, J. F. W., Waldmann, N., Goldstein, S. L., and Stein, M.: Evidence from Lake Lisan of solar influence on decadal- to centennial-scale climate variability during marine oxygen stage 2, Geology, 32, 581-584, doi:10.1130/G20553.1, 2004.

Preece, R. C., Parfitt, S. A., Bridgland, D. R., Lewis, S. G., Rowe, P. J., Atkinson, T. C., Candy, I., Debenham, N. C., Penkman, K. E. H., Rhodes, E. J., Schwenningerl, J.-L., Griffiths, H I., Whittaker, J. E., and Gleed-Owen, C.: Terrestrial environments during MIS 11: evidence from the Palaeolithic site at West Stow, Suffolk, UK, Quaternary Sci. Rev., 26, 1236-1300, doi:10.1016/j.quascirev.2006.11.016, 2007.

Reille, M., de Beaulieu, J.-L., Svobodova, H., Andrieu-Ponel, V., and Goeury, C.: Pollen stratigraphy of the five last climatic cycles in a long continental sequence from Velay (Massif Central, France), J. Quaternary Sci., 15, 665-685, 2000.

Risebrobakken, B., Jansen, E., Andersson, C., Mjelde, E., and Hevrøy, K.: A high-resolution study of Holocene paleoclimatic and paleoceanographic changes in the Nordic Seas, Paleoceanography, 18, PA1017, doi:10.1029/2002PA000764, 2003.

Rittenour, T. M., Brigham-Grette, J., and Mann, M. E.: 
El Niño-like climate teleconnections in New England during the Late Pleistocene, Science, 288, 1039-1042, doi:10.1126/science.288.5468.1039, 2000.

Rodó, X., Baert, E., and Comin, F. A.: Variations in seasonal rainfall in Southern Europe during the present century: relationships with the North Atlantic Oscillation and the El Niño-Southern Oscillation, Clim. Dynam., 13, 275-284, doi:10.1007/s003820050165, 1997.

Rohling, E. J. and Pälike, H.: Centennial-scale climate cooling with a sudden cold event around 8,200 years ago, Nature, 434, 975979, doi:10.1038/nature03421, 2005.

Rohling, E. J., Braun, K., Grant, K., Kucera, M., Roberts, A. P., Siddall, M., and Trommer, G.: Comparison between Holocene and Marine Isotope Stage 11 sea-level histories, Earth Planet. Sci. Lett., 291, 97-105, doi:10.1016/j.epsl.2009.12.054, 2010.

Ruddiman, W. F.: Cold climate during the closest Stage 11 ana$\log$ to recent Millennia, Quaternary Sci. Rev., 24, 1111-1121, doi:10.1016/j.quascirev.2004.10.012, 2005.

Sarnthein, M., Stremme, H. E., and Mangini, A.: The Holstein interglaciation: Time-stratigraphic position and correlation to stable-isotope stratigraphy of deep-sea sediments, Quaternary Res., 26, 283-298, doi:10.1016/0033-5894(86)90090-6, 1986.

Sarnthein, M., van Kreveld, S., Erlenkeuser, H., Grootes, P. M., Kucera, M., Pflaumann, U., and Schulz, M.: Centennial-tomillennial-scale periodicities of Holocene climate and sediment injections off the western Barents shelf, $75^{\circ} \mathrm{N}$, Boreas, 32, 447461, doi:10.1111/j.1502-3885.2003.tb01227.x, 2003.

Shindell, D. T., Schmidt, G. A., Mann, M. E., Rind, D., and Waple, A.: Solar forcing of regional climate change during the Maunder Minimum, Science, 294, 2149-2152, doi:10.1126/science.1064363, 2001.

Solanki, S. K., Usoskin, I. G., Kromer, B., Schüssler, M., and Beer, J.: Unusual activity of the Sun during recent decades compared to the previous 11,000 years, Nature, 431, 1084-1087, doi:10.1038/nature02995, 2004.

Stenseth, N. C., Ottersen, G., Hurrell, J. W., Mysterud, A., Lima, M., Chan, K.-S., Yoccoz, N. G., and Ådlandsvik, B.: Studying climate effects on ecology through the use of climate indices: the North Atlantic Oscillation, El Niño Southern Oscillation and beyond, P. Roy. Soc. B, 270, 2087-2096, doi:10.1098/rspb.2003.2415, 2003.

Stuiver, M. and Braziunas, T. F.: Sun, ocean, climate and atmospheric ${ }^{14} \mathrm{CO}_{2}$ : an evaluation of causal and spectral relationships, Holocene, 3, 289-305, doi:10.1177/095968369300300401, 1993.
Stuiver, M., Grootes, P. M., and Braziunas, T. F.: The GISP2 $\delta 180$ climate record of the past 16,500 years and the role of the sun, ocean, and volcanoes, Quaternary Res., 44, 341-354, doi:10.1006/qres.1995.1079, 1995.

Theissen, K. M., Dunbar, R. B., Rowe, H. D., and Mucciarone, D. A.: Multidecadal- to century-scale arid episodes on the northern Altiplano during the middle Holocene, Palaeogeogr. Paleocl., 257, 361-376, doi:10.1016/j.palaeo.2007.09.011, 2008.

Torrence, C. and Compo, G. P.: A practical guide to wavelet analysis, B. Am. Meteorol. Soc., 79, 61-78, 1998.

Turner, C.: The Middle Pleistocene deposits at Marks Tey, Essex, Philos. T. R. Soc. B, 257, 373-440, doi:10.1098/rstb.1970.0029, 1970.

Tzedakis, P. C.: The MIS 11 - MIS 1 analogy, southern European vegetation, atmospheric methane and the "early anthropogenic hypothesis", Clim. Past, 6, 131-144, doi:10.5194/cp-6-131-2010, 2010.

Tzedakis, P. C., Raynaud, D., McManus, J. F., Berger, A., Brovkin, V., and Kiefer, T.: Interglacial diversity, Nat. Geosci., 2, 751755, doi:10.1038/ngeo660, 2009.

Vautard, R., Yiou, P., and Ghil, M.: Singular-spectrum analysis: A toolkit for short, noisy chaotic signals, Physica D, 58, 95-126, doi:10.1016/0167-2789(92)90103-T, 1992.

Visbeck, M. H., Hurrell, J. M., Polvani, L., and Cullen, H. M.: The North Atlantic Oscillation: Past, present, and future, P. Natl. Acad. Sci. USA, 98, 12876-12877, doi:10.1073/pnas.231391598, 2001.

Vos, H., Sanchez, A., Zolitschka, B., Brauer, A., and Negendank, J. F. W.: Solar activity variations recorded in varved sediments from the crater lake of Holzmaar - a maar lake in the Westeifel volcanic field, Surv. Geophys., 18, 163-182, doi:10.1023/A:1006531825130, 1997.

Wanner, H., Brönnimann, S., Casty, C., Gyalistras, D., Luterbacher, J., Schmutz, C., Stephenson, D. B., and Xoplaki, E.: North Atlantic Oscillation - concepts and studies, Surv. Geophys., 22, 321-381, doi:10.1023/A:1014217317898, 2001.

Weedon, G.: Time-series analysis and cyclostratigraphy. Cambridge University Press, UK, 2003.

Zolitschka, B.: Climatic change evidence and lacustrine varves from maar lakes, Germany, Clim. Dynam, 6, 229-232, doi:10.1007/BF00193553, 1992. 